\title{
Influence of Societal Factor on the Emergence of Language Variants:

\author{
The Study of Indonesia Language Use in Javanese Society
}

\author{
Dwi Atmawati \\ Balai Bahasa Daerah Istimewa Yogyakarta, Indonesia \\ dwi_bbs@yahoo.co.id
}

\begin{abstract}
Language is part of national culture that can be used as living recording media. In social life, the use of language is influenced by societal factor. It has emerged language variants. They can be met such as in Javanese utterance society. Dealing with that, the researcher reviews the societal factor influence to the use of Indonesia language in Javanese society. In this research used qualitative descriptive method. Data obtained from oral and written sources with recording, reading, and record techniques. Furthermore, the data were analyzed by using the method of padan and agih method from Sudaryanto (1995) and Mahsun (2005). The result of the research shows that societal factor has emerged language variants in Javanese society. Those language variants emerged when the speaker uses Indonesia language such as words sowan 'visit', dhahar 'eat', pinarak 'stay', mirsani 'see', lenggah 'sit', menghaturkan 'say', tindak 'go', rawuh 'come', tapak asta 'signature', matur 'talk'. Those words choice from Javanese language are sometimes hold by speakers although they use Indonesia language as their communication. Those Javanese words are used by the speakers or older receivers who are respected for courtesy. Those words are sowan, dhahar, pinarak, mirsani, lenggah, menghaturkan, tindak, rawuh, tapak asta, matur are karma form in Javanese language, there are language levels in communication, ngoko and krama. On the other hand, Indonesia language has fewer words which show level of speaking than in Javanese language.
\end{abstract}

Keywords—societal factor; Java; variants; polite; krama

\section{INTRODUCTION}

Language is not determined only by structural factors, but also by societal factors. Those structural factors are associated to linguistic aspect, while the societal factors are associated to variation choosing. Within social cultural context, language besides functions as communication means also functions as means to set relationship, either inter individuals, groups, or individual to group. As the cultural phenomena, language is the place for culture. Good relationship will be set up in communication if the speaker and listener notice the cultural norms in the place of the dialog happen. Therefore, the cultural norms in a society can be reflected through language. Through vocabulary choosing, it can be identified the cultural, the social status of the speaker to the listener, the circumstance of the happening dialog. As the social phenomena, language is inseparable from daily human life. The social factors which influence speaking such as relationship of the role between speaker and listener, education, age, sex, place of the action, aim of speaking, social status. In the Javanese society developed the Java language, Indonesian, and foreign languages. The Java community has a culture associated with the use of Javanese. The culture gives high appreciation values to the respected people.

Existence of any factors has influence to the choosing of language forms to use. Choosing to language forms can stimulate language variation. Besides that, language variation can emerge for the difference of language function. In Javanese society, choosing to language forms can be found, either oral or written speaking. The choosing to language forms can be identified clearly in speaking using Indonesia language by involving Javanese speaker with different ages, social status, situation, and speaking aims. It so happens because Javanese society has undha-usuk (speech level) in Javanese language. Undha-usuk in Javanese language is reflected when the Javanese speaker uses Indonesia language.

By concerning the language phenomena of Javanese society, the researcher is interested in revealing how far the Javanese language vocabularies appear in Indonesia language speaking caused by societal factor. By understanding the phenomena, it is expected that speakers from different culture from Javanese society are able to adapt with speaking situation and place of speaking.

This research refers to the theory of speaking components by Hymes (1972), courtesy norms in language from Poedjosoedarmo (1978) and language variation Poedjosoedharmo (1983), cooperation principle and well mannered guidance from Leech (1983). Hymes (1072) formulates speaking speech components as follows. Setting refers to the time and place of the act of speech. Participant refers to speaker, sender, listener, recipient. End refers to the intended speech and expected results. Act sequence refers to: how to convey the topic and message content. Key refers to the way, the tone in doing speech acts. Instrument refers to the delivery medium is oral or written form. Norms refers to the norms of interaction and interpretation norms. The genre refers to the form of poetry, myth, myth, oration, editorial, and so on.

In Poedjosoedarmo's (1978) poignant language norms argue that the speaker (P1) should be friendly, willing to listen and respond to the addressee (P2), not focusing on himself, saying the truth and not lying. P1 gives full attention to $\mathrm{P} 2$ or one or more person who happen to be around (P3), adjust the language used $\mathrm{P} 2 / \mathrm{P} 3$ by paying attention to speech level, as well as speech acts, pleasing P2/P3. Speakers should also pay 
attention to speech events, speaking according to the situation, purpose, and topic. Formal or informal speech styles should also be chosen accordingly. Speakers use appropriate instruments, namely oral, written, electronic, sound (loud/weak/medium), or gestures. Speakers should use speech acts efficiently, only convey the points, the paragraphs/sentences are brief, discourse/speech is clear, makes sense, contains wholeness, interconnected, and implicatur not too far with the topic. Speech delivered smoothly, easily understood. When an idiom/metaphor is used, it should be an easy idiom/metaphor. In addition, the rhythm of speech should also be appropriate. Due to language variation, Poedjosoedharmo (1983:175-176) stated that there is three language variant classes. Those variants are: (1) dialect such as idiolect and dialiect (geography, social age, type, group, ethnic, etc.); (2) speech level (respect, not respect), and (3) types (informal, formal, and interesting). The variety of forms used, for example, the peculiarities in the use of diversity if any, whether or not it can properly declare the official variety and suitability, in the absence of the official use of the variety with the applicable in the community. The form of unnamed used, for example, in accordance with the forms of expression with the politeness of the prevailing language. The commonly used forms of dialect.

\section{REVIEW OF RELATED LITERATURE}

The related research that has been conducted among others titled "Faktor Penentu Penggunaan Bahasa pada Masyarakat Tutur Makassar: Kajian Sosiolinguistik di Kabupaten Gowa" by Hasyim (2008). "The result of the study show several finding which determine the use of the language: (a) skill of using the language; (b) setting and situation; (c) participans; (d) objectives of speech."

Furthermore, the study is titled "Pemakaian Bahasa Sinjab di Kawasan Kota, Kabupaten Batang” by Laeis (2012). "The result of the study was the Sinjab vocabulary which consists of the original and derivative Sinjab language. Sinjab language was used when a group of people are talking about the things that do not want to be known by another people, so the use of Sinjab language is to conceal the speech" (Laeis, 2012:1). In a study entitled "Language and Culture" it is argued that "there is a very close relationship between language and culture. That is, culture has a direct effect on language. Language and culture are closely correlated" (Mahadi and Jafari, 2012:230). Furthermore, the study is titled "Politeness Orientation in Social Hierarchies in Urdu" by Kousar (2015). "The results showed that Pakistani society is non-egalitarian. Moreover, this study supports Brown and Levinson's (1978, 1987) claim for universality of politeness in preferring negative politeness to positive politeness; though, this preference for negative politeness is the outcome of the unequal social status of the addressee (Kousar, 2015:85). According to Brown and Levinson (1987), which was inspired by Goffman (1967), that being polite is to be concerned with "face" or "face," both the speaker's and the partner's. "Face," in that case, it is not in the physical sense, but the "face" in the sense of public image, or perhaps the exact equivalent of the word is "self-esteem" in the eyes of society. Brown and Levinson (1987) mentioned that the face is a personal attribute that is owned by every human being and is universal. In this theory, the face is then divided into two types: the face with positive desire (positive face), and face with negative desire (negative face). The positive face is associated with the value of solidarity, ignorance, recognition. The context of language politics includes the context of the situation, the social context, and the cultural context. Modesty is a pragmatic phenomenon that is influenced by context. There are two context situations that affect how to request. First, the degree of coercion, and the rule is "the higher the rate of impression a speech imparts, the more indirectly a utterance". The choice of politeness formulation depends on social distance and power between the two parties. When there is social distance, politeness is encoded and there is a lot of speech incoordination. As social distance decreases, there is less negative politeness and insecurity. The variables that determine social distance are the level of familiarity, status differences, roles, age, gender, education, class, occupation and ethnicity. Language politeness is bound by local culture.

The study entitled "Pilihan Bahasa dalam Masyarakat Multilingual di Kemujan Karimunjawa Jepara" among others describe "domain which is the language choice within the multilingual community in Kemujan Karimunjawa Jepara" (Niswa dan Mukhlish, 2017:110). The next related study is entitled "The Relationship between Language and Culture" by Rangriz and Harati (2017). In the study it was proposed that "language can be viewed as a verbal expression in learning a second or foreign language it is possible to separate language and culture" (Rangriz and Harati, 2017:209). Svendsen points out that "The Research Campaign engaged pupils in research; it ensured reciprocity by securing a two-way communication with the citizens (and their teachers) in the process; in that it sought to contribute to the citizens by including the pupils' research questions; it provided the database in which they themselves contributed data to be explored in (or outside of) the classroom; it provided the various reflexive ethnographic tasks on the interrelation between language and social diversity to stimulate language awareness through more research activities, by providing the research report as well as including the Research Campaign in activities and venues for the general public; it sought to contribute to the scientific field by being able to tap into large-scale national data on language competence, practices and attitudes" (Svendsen, 2018:73).

This research needs to be done so that speakers who are not Javanese society know about politeness in language related to Javanese society culture. Thus, communication can take place smoothly so that conflicts that may arise due to lack of choice of words can be avoided. It is given that in the Java community is known the level of speech. The speech level is very diverse. Its use is strongly influenced by social status, age, and kinship relationships.

\section{METHOD}

This research used descriptive qualitative method. Data obtained from oral and written sources. Oral source in question is oral conversation. The source of writing comes from the internet media. Data derived from oral sources is obtained from oral conversations by listening, listening, and 
recording them. Data were collect using watching, listening, recording, and writing. The data sources are written and spoken. The researcher recorded sentences and spoken dealing with the topic of the research. Besides that, researcher uses language use in sentences forms reflecting societal factor from written source. After the data collected, the analysis is performed to the data.

\section{FINDINGS AND DISCUSSION}

\section{A. Findings}

The use of language of society sometimes gives different variation one another. The variation can be caused by differences dealing with culture, like relationship of social status-role, value system in society. The variants use language as societal factor impact as follow. Here are the uses of language by Javanese speaker. The place of speaking is in central Java district.

(1) Kami menghaturkan 'mengucapkan' terima kasih. 'We say thank you'.

(2) Sugeng rawuh 'selamat datang' di Kabupaten Magelang. 'Welcome to Magelang regency'.

(3) ... tak ada bunyi apapun selain pangendikan 'ucapan' Gus Dur. 'there is no voice besides speech of Gus Dur'

(4) Besok saya akan sowan 'mengunjungi' Bapak. 'Tomorrow I shall visit Bapak'.

(5) Bapak sedang dhahar 'makan' dengan tamu. 'Father is eating with guest'.

(6) Silakan Ibu pirsani 'lihat'. 'Please, mother sees'.

(7) Beliau lenggah 'duduk' di ruang transit. 'He sits in transit room'.

(8) Kami mohon Bapak Gubernur membuka acara secara resmi. 'We ask the Governor to open the program officially'.

(9) Bapak baru saja tindak 'berangkat' rapat. 'Father has just left to have meeting'.

(10) Silakan Ibu pinarak 'singgah' ke rumah saya. 'Please, Mother stay in my house'.

(11) Kami masih menunggu tapak asma 'tanda tangan' pimpinan. 'We are still waiting for signature of the headmaster'.

(12) Apakah kamu sudah matur 'berbicara' dengan Bapak? 'Have you told Bapak?'

(13) Beliau memang sudah sepuh 'tua', tapi pendengaran dan penglihatannya masih bagus. 'He is old indeed, but his listening and vision are still good'.

Those examples show that the variants were selected because of sociological goals to gain. The cultural factor is tightly associated to language forms selection. Greeting word bapak tends not to be used in the country which uses English language as communication language. British society tends to greet name directly. It is different from Javanese society. The greeting word bapak is exactly used to admire to adult men, elderly, officials or leader. The word dhahar in Javanese society cannot be used arbitrarily. It is usually used in regard to his partner of speaking.
Additionally, words menghaturkan, sugeng rawuh pangendikan, sowan, pirsani, lenggah, bapak gubernur, tindak, pinarak, tapak asma, matur, sepuh are selected to respect more to partner of speaking and to show status social difference. Words selection of menghaturkan, sugeng rawuh, pangendikan, sowan, dhahar, pirsani, lenggah, bapak gubernur, tindak, pinarak, tapak asma, matur, sepuh is usually addressed to older and respected people, leaders or functionaries. The word mengucapkan is equal to menghaturkan, sugeng rawuh to selamat datang, pangendikan to ucapan, sowan to mengunjungi, dhahar to makan, pirsani to lihat, lenggah to duduk, gubernur (without greeting bapak), tindak to berangkat, pinarak to singgah, tapak asma to tanda tangan, matur to berbicara, sepuh to tua are usually used to neutral meaning. Vocabularies of mengucapkan, selamat datang, ucapan, mengunjungi, makan, lihat, duduk, gubernur, berangkat, singgah, tanda tangan, berbicara, tua are able to be used by speakers from any groups, regarding ages, sex or social status.

Language politeness is governed by community norms and morality that are internalized in a cultural context. Language norms have evolved in verbal communication. Based on the comparative data above, it is known that although vocabulary has same meaning in structural linguistic, the sociolinguistic aspect still has to be noticed to understand the whole language phenomena. Therefore, the direct speaking goes fluently for the courtesy norms in speaking are fulfilled. Conflict appears because unavoidable language forms choosing. Therefore, linguistic and non-linguistic factors in speaking need to be noticed.

\section{B. Discussion}

In the Javanese society there is a known speech level. The level of Javanese speech outline includes Javanese ngoko and krama. Javanese krama language is still storied as well. These levels are krama madya and krama alus. Selection of speech level in Javanese is influenced by among others factors of age, sex, social status, education level.

In this study found the difference in the use of speech levels in the Javanese language that participated in coloring the Indonesian language speech. Based on the data, it is known that the Javanese community in the Indonesian language speech in nonformal or semiformal situations sometimes insert a Javanese vocabulary with the aim of more respect for the partners. As in previous research more describes the use of mixed code. The code mixing study discussed mostly mixed codes, both Javanese and foreign (English, Arabic) into Indonesian.

\section{CONCLUSION}

The result of the research shows that societal factor has emerged language variants in Javanese society. Those language variants emerged when the speaker uses Indonesia language such as words sowan 'visit', dhahar 'eat', pinarak 'stay', mirsani 'see', lenggah 'sit', menghaturkan 'say', tindak 'go', rawuh 'come', tapak asta 'signature', matur 'talk'. Those words choice from Javanese language are sometimes hold by speakers although they use Indonesia language as their 
communication. Those Javanese words are used by the speakers or older receivers who are respected for courtesy. Those words are sowan, dhahar, pinarak, mirsani, lenggah, menghaturkan, tindak, rawuh, tapak asta, matur are karma form in Javanese language, there are language levels in communication, ngoko and krama. On the other hand, Indonesia language has fewer words which show level of speaking than in Javanese language.

\section{References}

Brown, P. \& Levinson, S. C. (1978). Universals in language usage: Politeness phenomena. In Esther N. Goody. (Editor), Questions and politeness: Strategies in social interaction. Cambridge: Cambridge University Press.

Hasyim, M. (2008). Faktor penentu penggunaan bahasa pada masyarakat tutur Makassar: Kajian sosiolinguistik di Kabupaten Gowa. Jurnal Humaniora, 20(1), 75-88. https://jurnal.ugm.ac.id/jurnal-humaniora/article/view/921

Hymes, D. (1972). Models of the interaction of language and social life. In Gumpers dan Hymes. (Eds.), .Direction of sociolinguistics. New York: Holt, Rinehart and Winston.

Kousar, S. (2015). Politeness orientation in social hierarchies in Urdu. International Journal of Society, Culture \& Language, 3(2), 85-96. http://ijscl.net/article_11868.html

Laeis, L. (2012). Pemakaian bahasa Sinjab di Kawasan Kota, Kabupaten Batang. Jurnal Sastra Indonesia. 1(2), 1-7.
Mahadi, T. S. T. \& Jafari, S. M. (2012). Language and culture. International Journal of Humanities and Social Science, 2(17), 230-235. https://www.ijhssnet.com/journals/Vol_2_ No_17_September_2012/24.pdf

Mahsun. (2005). Metode penelitian bahasa. Jakarta: PT Raya Grafindo Persada.

Niswa \& Mukhlish. (2017). Pilihan bahasa dalam masyarakat multilingual di Kemujan Karimun Jawa Jepara. Jurnal Caraka 3(2), 110-126. jurnal.ustjogja.ac.id/index.php/ caraka/article/download/.../1059

Poedjosoedarmo, S. (1978). Language etiquette in Endonesian. In S. Udin. Editor, Spectrum: Essays Presented to Sutan Takdir Alisjahbana on his seventieth birthday. Jakarta: Dian Rakyat.

Poedjosoedarmo, S. (1983). Pengantar sosiolinguistik. Fakultas Sastra, Universitas Gadjah Mada (belum diterbitkan).

Rangriz, S. and Harati, M. (2017). The relationship between language and culture. Journal of Applied Linguistics and Language Research 4(6), 209-213. www.jallr.com/ index.php/JALLR/article/viewFile/677/pdf677

Svendsen, B. A. (2018). The dynamics of citizen sociolinguistics. Journal of Sociolinguistics 22(2), 137160. doi: 10.1111/josl.12276. Retrieved from https://onlinelibrary.wiley.com/doi/full/10.1111/josl.12276 